Prive; Volume 3, Nomor 2, September 2020 http://ejurnal.unim.ac.id/index.php/prive

Online ISSN 2615-7314

Printed ISSN 2615-7306

\title{
PENGARUH PROFITABILITAS DAN KEPEMILIKAN INSTITUSIONAL TERHADAP NILAI PERUSAHAAN DENGAN STRUKTUR MODAL SEBAGAI VARIABEL MODERASI PADA PERUSAHAAN PROPERTY DAN REAL ESTATE DI BEI PERIODE 2015-2018
}

\author{
Tatas Ridho Nugroho', Umi Muawanah², Djuni Farhan ${ }^{3}$ \\ 1,2,3Program Pascasarjana, Universitas Gajayana Malang \\ tatasridho14@gmail.com
}

\begin{abstract}
This research aims to see and analyze the effect of profitability and institutional ownership on firm value with the moderating variable capital structure in Property and Real Estate Companies on the IDX for the 2015-2018 period. The population in this study were 48 companies. The sampling technique used purposive sampling technique, the number of companies used as a sample is 25 companies and the data obtained is 100 data. Data analysis was performed through the SPSS program. The data analysis methods used are: descriptive statistical test, classical assumption test, linear multiple analysis and hypothesis testing. The results showed that the variable profitability proxied using ROE (Return on Equity) had an effect on firm value, institutional ownership variables had no effect on firm value, the variable capital structure was able to moderate and the relationship between profitability on firm value and capital structure variables was unable to moderate. The relationship between institutional ownership and the value of property and real estate companies listed on the Indonesia Stock Exchange for the period 20152018 .
\end{abstract}

Keywords: Profitability, ROE, Institutional Ownership, Firm Value, Capital Structure

\begin{abstract}
Abstrak
Penelititan ini bertujuan untuk mengetahui dan menganalisis pengaruh profitabilitas dan kepemilikan institusional terhadap nilai perusahaan dengan struktur modal sebagai variabel pemoderasi pada Perusahaan Property dan Real Estate di BEI periode 2015-2018. Populasi dalam penelitian ini adalah sebanyak 48 perusahaan. Teknik pengambilan sampel dilakukan dengan teknik purposive sampling maka jumlah perusahaan yang digunakan sebagai sampel adalah 25 perusahaan dan data yang diperoleh sebanyak 100 data. Analisis data dilakukan melalui program SPSS. Metode analisis data yang digunakan yaitu: uji statistik deskriptif, uji asumsi klasik, analisis regresi linear berganda dan uji hipotesis. Hasil penelitian menunjukkan bahwa variabel profitabilitas yang di proksikan menggunakan ROE (Return On Equity) berpengaruh terhadap nilai perusahaan, variabel kepemilikan institusional tidak berpengaruh terhadap nilai perusahaan, variabel struktur modal mampu memoderasi dan memperkuat hubungan antara profitabilitas terhadap nilai perusahaan dan variabel struktur modal tidak mampu memoderasi hubungan antara kepemilikan institusional terhadap nilai perusahaan Property dan Real Estate yang terdaftar di Bursa Efek Indonesia periode 2015-2018.
\end{abstract}

Kata Kunci: Profitabilitas, ROE, Kepemilikan Institusional, Nilai Perusahaan, Struktur Modal 


\section{A. PENDAHULUAN}

Seiring dengan perubahan era industri, perusahaan mempunyai tujuan untuk mengoptimalkan value dari perusahaan. Firm value atau nilai dari perusahaan yang terlalu tinggi akan membuat investor merasa yakin dan tertarik untuk menginvestasikan kelebihan dananya pada perusahaan dikarenakan perusahaan memiliki prospek yang bagus (Simanjuntak \& Pangestuti, 2019). Firm value yang tinggi berkaitan dengan penilaian investor tentang tingkatan dari perusahaan yang sukses. Firm value yang tinggi membuat investor memperoleh return yang tinggi dari nilai investasi (Hermuningsih, 2012). Firm value merupakan nilai pasar dari suatu ekuitas perusahaan ditambah nilai pasar hutang. Berikut adalah data perkembangan nilai perusahaan yang diukur dengan rumus Tobin's q:

Tabel 1. Perkembangan Nilai Perusahaan Property dan Real Estate di Bursa Efek Indonesia Periode 2015-2018

\begin{tabular}{ccc}
\hline Tahun & Rata-rata Tobin's q (\%) & $\begin{array}{c}\text { Perkembangan Tobin's q } \\
(\mathbf{\% )}\end{array}$ \\
\hline 2015 & 68,75 & - \\
\hline 2016 & 66,88 & $-1,87$ \\
\hline 2017 & 64,36 & $-2,53$ \\
\hline 2018 & 60,75 & $-3,61$ \\
\hline
\end{tabular}

Sumber : Data diolah penulis

Tabel di atas menunjukan penurunan firm value pada Perusahaan Property dan Real Estate di Bursa Efek Indonesia mulai tahun 2015 sampai 2018. Nilai perusahaan dapat menggambarkan keadaan perusahaan. Tinggi rendahnya nilai pemegang saham dipengaruhi oleh nilai perusahaan. Value dari shareholders meningkat jika nilai perusahaan juga ikut meningkat. Nilai perusahaan tinggi diindikasikan dengan rate pengembalian investasi yang tinggi kepada shareholders. Beberapa faktor yang bisa mempengaruhi nilai perusahaan dari berbagai penelitian adalah profitabilitas, size, Good Corporate Governance dan struktur modal. Penelitian ini berfokus pada faktor internal merupakan faktor esensial yang dapat memberi pengaruh dalam menentukan harga saham. Faktor internal suatu perusahaan indentik dengan fundamental keuangan dalam suatu analisis pasar modal. Faktor ini yang dapat dikontrol dalam pengendalian perusahaan.

Perusahaan yang go public yang terdaftar di BEI dituntut untuk mampu bersaing memperoleh laba yang sebesar-besarnya. Profitabilitas merupakan ukuran utama dari kinerja perusahaan dan merupakan indikasi kesuksesan dari sebuah perusahaan secara keseluruhan. Pada perusahaan yang telah go public. Kebijakan perusahaan tidak terlepas dari peran penting struktur kepemilikan institusional. Menurut Jensen dan Meckling (1976) "kepemilikan institusional berperan penting dalam meminimalkan konflik keagenan yang terjadi diantara pihak manajemen dengan pihak pemegang saham. Semakin tinggi prosentase kepemilikan institusional maka semakin banyak pula pihak yang mengawasi perusahaan sehingga diharapkan perusahaan dapat berjalan secara efektif. Kepemilikan institusional dapat diungkapkan melalui perbandingan antara kepemilikan saham institusi dengan total keseluruhan saham". Nilai perusahaan akan bertambah apabila kualitas dari laba perusahaan meningkat begitu pula sebaliknya. Nilai perusahaan juga dapat dioptimalkan melalui pengawasan yang dilakukan oleh kepemilikan institusional terhadap fungsi manajemen keuangan. Semakin besar tingkat prosentase kepemilikan institusional, maka semakin banyak pula pihak yang mengawasi perusahaan sehingga dapat meningkatkan nilai perusahaan.

Kebijakan pendanaan perusahaan untuk menentukan struktur modal ditujukan untuk mengoptimalkan nilai perusahaan. Struktur modal adalah bauran dari utang, saham biasa, dan saham preferen (Brigham dan Houston, 2011). Apabila laba perusahaan mengalami peningkatan maka tidak menutup kemungkinan utang perusahaan akan mengalami penurunan dan berakibat struktur modal juga semakin rendah, begitu pula sebaliknya. 
Pengendalian penggunaan utang ini dapat dilakukan dengan meningkatkan kepemilikan institusional.

Penelitian yang dilakukan oleh Andreas Aryanto Nong Moa (2017) menunjukkan bahwa profitabilitas dan srtuktur modal berpengaruh terhadap nilai perusahaan. Penelitian yang dilakukan oleh Abdul Wahab dan Anissa (2017) menunjukkan bahwa kepemilikan institusional berpengaruh terhadap nilai perusahaan. Berbeda dengan penelitian yang dikalukan oleh Wahyu Resdianty (2018) menunjukkan bahwa kepemilikan institusional tidak berpengaruh terhadap nilai perusahaan. Sedangkan untuk struktur modal menjadi variabel pemoderasi masih jarang dilakukan oleh peneliti sebelumnya.

Penelitian ini dilakukan pada perusahaan yang terdaftar di Bursa Efek Indonesia. Perusahaan yang diteliti adalah perusahaan property dan real estate selama periode 20152018. Peneliti memilih perusahaan property dan real estate dikarenakan pada tahun 2016 dapat dikatakan menjadi tahun buruk bagi perusahaan Property dan Real Estate.

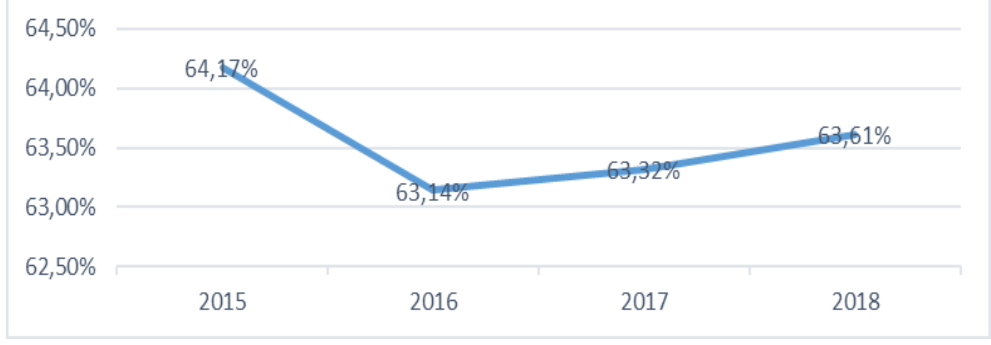

Sumber : Data diolah penulis

\section{Gambar 1. Grafik Kepemilikan Institusional}

Berdasarkan data yang terdapat di BEI saham-saham yang beredar di perusahaan Property dan Real Estate menurun sebesar 7,84\%. Menurut Direktur Investa Saran Mandiri Hans Kwee saham perusahaan Property dan Real Estate tahun terakhir masih agak sulit diminati oleh investor, hal ini dikarenakan tingkat penjualan yang menurun (www.mpi-update.com). Tingkat penjualan yang menurun ini kemungkinan terjadi dikarenakan tingkat kepemilikan institusional menurun pada tahun 2016 sehingga pengawasan kepada pihak manajemen berkurang. Dari grafik tersebut dapat dilihat terjadi penurunan kepemilikan institusional yang terjadi pada tahun 2016. Hal ini memperlihatkan terjadi salah satu masalah yakni kurangnya pengawasan kepada pihak manajemen oleh kepemilikan institusional. Selain itu adanya ketidak konsistenan dari hasil penelitian sebelumnya yang mendorong peneliti untuk meneliti variabel kepemilikan institusional, serta penggunaan Struktur Modal sebagai variabel pemoderasi masih jarang diteliti oleh reseachers sebelumnya, maka penulis tertarik untuk melaksanakan riset dengan judul "Pengaruh Profitabilitas dan Kepemilikan Institusional terhadap Nilai Perusahaan dengan Struktur Modal sebagai Variabel Moderasi pada Perusahaan Property dan Real Estate di BEI Periode 2015-2018”.

\section{B. TELAAH LITERATUR DAN PENGEMBANGAN HIPOTESIS}

Nilai profitabilitas yang tinggi merupakan sinyal yang positif bagi investor maupun kreditur yang menggambarkan bahwa kondisi perusahaan sedang mengalami keuntungan, hal ini dapat menjadi faktor interesting bagi investor untuk memiliki saham perusahaan. firm value akan menjadi tinggi apabila permintaan saham perusahaan tinggi, sehingga akan mempengaruhi calon investor lebih menghargai nilai saham. Berdasarkan hasil penelitin terdahulu yang dilakukan oleh Wahyuni, T., Ernawati, E., \& Murhadi, W. (2013). Yang menyatakan bahwa profitabilitas berpengaruh terhadap nilai perusahaan.

$H_{1}$ : Profitabilitas berpengaruh positif terhadap Nilai Perusahaan.

Kepemilikan institusional memiliki pengaruh yang menguntungkan dalam tata kelola suatu perusahaan. Semakin besar tingkat prosentase dari kepemilikan institusional maka semakin banyak 
pula pihak yang mengawasi perusahaan agar perusahaan dapat berjalan secara efektif dan dapat meningkatkan nilai perusahaan. Berdasarkan hasil penelitian yang dilakukan oleh Putri Aulia Rahmadina (2017) yang menyatakan bahwa kepemilikan institusional berpengaruh terhadap nilai perusahaan.

\section{$\mathrm{H}_{2}$ : Kepemilikan Institusional berpengaruh positif terhadap Nilai Perusahaan.}

Pada umumnya suatu perusahaan yang memiliki tingkat keuntungan yang tinggi akan membuat tingkat pengembalian yang tinggi pula. Hal ini berarti dana yang diperoleh dari pihak internal perusahaan lebih banyak dan memiliki tingkat utang yang lebih kecil. Tingkat utang yang lebih kecil ini karena perusahaan mempunyai kelebihan surplus cash flow yang nantinya dapat dipakai sebagai sumber dana di kemudian hari. Apabila semakin banyak keuntungan yang didapat oleh perusahaan, maka semakin rendah kebutuhan ekstenal (utang) sehingga membuat struktur modal semakin rendah. Apabila tingkat struktur modal rendah akan membuat nilai perusahaan semakin meningkat dan perspektif investor akan menilai perusahaan mampu untuk mendanai kegiatan operasional sendiri tanpa menggunakan utang yang beresiko. Pihak investor menyukai perusahaan yang memberikan keuntungan yang tinggi bagi pemegang saham, sehingga nantinya investor akan bersedia membayar untuk mendapatkan saham diperusahaan dan nantinya akan berdampak pada naiknya firm value.

\section{$H_{3}$ : Struktur Modal mampu memoderasi hubungan antara Profitabilitas terhadap Nilai Perusahaan.}

Penentuan kepemilikan institusional dapat diukur dengan pertimbangan antara "proporsi kepemilikan saham institusi dengan jumlah saham yang beredar". Agensi teori menyatakan apabila tingkat kepemilikan institusional yang tinggi akan membuat usaha pengawasan yang lebih besar sehingga dapat mengontrol pengambilan keputusan oleh manajer yang berhubungan dengan struktur modal. Pengawasan kepemilikan institusional yang efektif akan menggantikan peran utang sebagai alat kontrol manajemen. Struktur modal erat hubungannya dengan modal eksternal (utang). Jika perusahaan mengalami keterbatasan modal dari pihak internal perusahaan, maka struktur modal akan mengalami kenaikan. Hal ini dapat menuntut pihak manajemen untuk mencari struktur modal dengan tingkat yang seimbang antara utang dengan modal. Dengan adanya hal ini investor akan beranggapan bahwa perusahaan memiliki kinerja yang baik dan menunjukkan tingkat keefektifan pengawasan dari kepemilikan institusional sehingga nantinya dapat memikat calon investor untuk membeli saham di perusahaan dan dapat meningkatkan firm value.

$H_{4}$ : Struktur Modal mampu memoderasi hubungan antara Kepemilikan Institusional terhadap Nilai Perusahaan.

\section{METODE PENELITIAN}

\section{Populasi dan Sampel}

Penelitian ini merupakan penelitian kauntitatif yang analisisnya menekan pada angka atau numerical yang diperoleh melalui metode statistik. Populasi dalam riset ini adalah Perusahaan property dan real estate yang terdaftar di Bursa Efek Indonesia pada tahun 2018 sebanyak 48 perusahaan dimana seluruh perusahaan property dan real estate dijadikan sebagai populasi. Dari populasi yang digunakan dapat di tentukan besarnya sampel dan menggunakan teknik purposive sampling. Adapun penentuan sampel perusahaan berdasarkan kriteria yang telah disajikan berikut:

\section{Tabel 2. Sampel Penelitian}

\begin{tabular}{clc}
\hline No & \multicolumn{1}{c}{ Kriteria Sampel } & Jumlah \\
\hline 1 & $\begin{array}{l}\text { Perusahaan property dan real estate yang terdaftar di Bursa } \\
\text { Efek Indonesia periode 2015- 2018. }\end{array}$ & 48 \\
\hline 2 & $\begin{array}{l}\text { Perusahaan yang mengeluarkan laporan keuangan dan laporan } \\
\text { tahunan secara berturut turut pada periode 2015-2018. }\end{array}$ & 45 \\
\hline 3 & $\begin{array}{l}\text { Perusahaan yang memperoleh laba selama } 4 \text { periode yang } \\
\text { diteliti yaitu periode tahun 2015-2018. }\end{array}$ & 34 \\
\hline 4 & $\begin{array}{l}\text { Perusahaan yang memiiki data mengenai variabel yang } \\
\text { dibutuhkan dalam penelitian secara lengkap dari periode tahun }\end{array}$ & 25 \\
& 2015-2018. & $\mathbf{2 5}$ \\
\hline Jumlah sampel perusahaan & $\mathbf{4}$ \\
\hline Tahun yang diteliti & $\mathbf{1 0 0}$ \\
\hline Jumlah data penelitian
\end{tabular}

Sumber : Data diolah penulis 
Berdasarkan penentuan sampel yang dilakukan diperoleh sebanyak 25 perusahaan property dan real estate yang digunakan sebagai sampel dalam penelitian serta periode yang digunakan selama 4 tahun sehingga data yang diolah sebanyak 100 data penelitian.

\section{Teknik Pengumpulan dan Analisis Data}

Teknik Pengumpulan data dalam riset ini menggunakan data sekunder yang diperoleh peneliti dari situs resmi www.idx.co.id .Peneliti menggunakan data kuantitatif yang berupa angka. Aplikasi untuk mengolah data menggunakan SPSS versi 22 dengan tahapan pengujian regresi linier berganda sebagai berikut, yaitu: (1) Uji Normalitas, (2) Uji Multikolinearitas, (3) Uji Autokorelasi, (4) Uji Heteroskedastisitas, (5) Uji Regresi Linier Berganda dan (6) Uji Hipotesis.

\section{Variabel Penelitian}

\section{a. Varibel Dependen (Y)}

Nilai perusahaan merupakan suatu pemahaman dari seorang investor pada tingkat perusahaan sedang mengalami kinerja yang baik serta dikaitkan dengan harga saham perusahaan.

\section{b. Variabel Independen (X)}

\section{1) Profitabilitas $\left(\mathbf{X}_{1}\right)$}

"Rasio profitabilitas adalah rasio yang digunakan dalam mengukur tingkat pengembalian ataupun perolehan keuntungan dibandingkan dengan tingkat penjualan atau aktiva. Rasio ini juga digunakan untuk mengukur seberapa besar kemampuan suatu perusahaan dalam memperoleh laba sebesar-besarnya" (Wiratna Sujarweni, 2015).

\section{2) Kepemilikan Institusional $\left(\mathbf{X}_{2}\right)$}

Kepemilikan institusional merupakan kepemilikan saham perusahaan oleh lembaga lain atau institusi lain seperti halnya perusahaan investasi, asuransi, perbankan dan lembaga lainnya. Kepenilikan instusional bisa mengendalikan pihak manajemen melalui pengawasan yang maksimal sehingga menjamin peningkatan kemamkmuran pemegang saham.

\section{c. Variabel Moderasi $(\mathbf{Z})$}

Struktur modal adalah campuran sumber-sumber dana jangka panjang yang digunakan oleh perusahaan (Keown dan Martin, 2010). Sumber dana tersbut bisa berasal dari pihak internal perusahaan seperti laba ditahan dan sumber dana eksternal yang berasal dari para kreditur dan para pemegang saham.

Berikut ini merupakan tabel pengukuran variabel dalam penelitian:

\section{Tabel 3. Pengukuran Variabel}

\begin{tabular}{|c|c|c|c|}
\hline \multirow{2}{*}{$\begin{array}{c}\text { No } \\
1\end{array}$} & Variabel & Pengukuran & Skala \\
\hline & $\begin{array}{c}\text { Profitabilitas } \\
\left(\mathrm{X}_{1}\right)\end{array}$ & $\begin{array}{l}\text { Profitabilitas diukur menggunakan ROE (Return On Equity). ROE dianggap penting bagi } \\
\text { pemegang saham karena ROE dapat mengetahui efisiensi dan efektifitas pengolahan modal } \\
\text { sendiri yang dilakukan oleh pihak manajemen perusahaan. ROE dapat dihitung dengan } \\
\text { menggunakan rumus: ROE }=\frac{\text { Laba bersi } h}{\text { Talon }}\end{array}$ & Rasio \\
\hline 2 & $\begin{array}{c}\text { Kepemilikan } \\
\text { Institusional } \\
\left(\mathrm{X}_{2}\right)\end{array}$ & $\begin{array}{l}\text { Kepemilikan saham institusional diukur dengan perbandingan antara jumlah kepemilikan } \\
\text { saham institusi dengan jumlah saham yang beredar. Kepemilikan institusional secara } \\
\text { matematis dirumuskan sebagi berikut: } \\
\mathrm{KI}=\frac{\text { Saham Institusi }}{\text { Total keseluru han saham }} \times 100 \%\end{array}$ & Rasio \\
\hline 3 & $\begin{array}{c}\text { Struktur } \\
\text { Modal (Z) }\end{array}$ & $\begin{array}{ll}\text { nilai perusahaan diukur dengan Tobin's } \mathrm{Q} \text {. Tobin's } \mathrm{Q} \text { dapat dihitung dengan rumus: Tobin's } \\
\begin{array}{ll}\mathrm{Q}=\frac{(E M V+D)}{(E B V+D)} & \\
\text { Keterangan: } & =\text { nilai perusahaan } \\
\mathrm{Q} & =\text { closing price } \mathrm{x} \text { jumlah saham yang beredar } \\
\text { EMV (Equity Market Value) } & =\text { nilai buku dari total aktiva } \\
\text { EBV (Equity Book Value) } & =\text { nilai buku dari total hutang }\end{array}\end{array}$ & Rasio \\
\hline 4 & $\begin{array}{c}\text { Nilai } \\
\text { Perusahaan } \\
(\mathrm{Y})\end{array}$ & $\begin{array}{l}\text { Dalam mengukur nilai perusahaan peneliiti menggunakan DER dirumuskan sebagai berikut: } \\
\text { DER }=\frac{\text { Total hutang }}{\text { Toatal ekuitas }}\end{array}$ & Rasio \\
\hline
\end{tabular}

Sumber : Data diolah penulis 


\section{HASIL DAN PEMBAHASAN}

\section{Hasil Penelitian}

Hipotesis pada penelitian ini diuji menggunakan persamaan regresi. Analisis data yang digunakan sebagai berikut:

\section{a. Uji Statistik Deskriptif}

Analisis data deskriptif bertujuan memberikan gambaran dan mendeskrisikan obyek yang diteliti melalui data sampel.

Tabel 4. Hasil Analisis Statistik Deskriptif

\begin{tabular}{lccccc}
\hline & N & Minimum & Maximum & Mean & Std. Deviation \\
\hline Profitabilitas & 100 & .04 & 32.21 & 8.6910 & 6.37879 \\
\hline Kepemilikan Institusional & 100 & 42.32 & 88.56 & 63.5678 & 12.96069 \\
\hline Nilai Perusahaan & 100 & 19.95 & 128.39 & 64.8896 & 23.94702 \\
\hline Struktur Modal & 100 & 4.33 & 183.37 & 74.9428 & 46.43570 \\
\hline Valid N (listwise) & 100 & & & & \\
\hline
\end{tabular}

Sumber : Data diolah output SPSS 22, 2019

Berdasarkan Tabel 4 di atas, hasil analisis variabel profitabilitas menunjukkan nilai minimum sebesar 0,04 maksimum sebesar 32,21 dengan rata-rata sebesar 8,6910 dan standar deviasi 6,37879. Selanjutnya kepemilikan institusional menunjukkan nilai minimum sebesar 42,32 maksimum sebesar 88,56 dengan rata-rata sebesar 63,5678 dan standar deviasi sebesar 12,96069. Hasil analisis variabel dependen menunjukkan nilai minimum 19,95 maksimum sebesar 128,39 dengan rata-rata sebesar 64,8896 dan standar deviasi sebesar 23,94702. Hasil analisis variabel struktur modal menunjukkan nilai minimum 4,33 maksimum 183,37 dengan rata-rata 74,9428 dan standar deviasi 46,43570.

\section{b. Uji Asumsi Klasik}

Uji asumsi klasik dalam penelitian ini berupa uji normalitas, multikolinearitas, autokorelasi dan heteroskedastisitas. Berikut adalah hasil pengujian asumsi klasik.

\section{Tabel 5 Hasil Uji Normalitas}

\begin{tabular}{|c|c|c|c|c|c|}
\hline \multicolumn{6}{|c|}{ One-Sample Kolmogorov-Smirnov Test } \\
\hline & & Profitabilitas & $\begin{array}{l}\text { Kepemilikan } \\
\text { Institusional }\end{array}$ & $\begin{array}{c}\text { Nilai } \\
\text { Perusahaan }\end{array}$ & $\begin{array}{c}\text { Struktur } \\
\text { Modal }\end{array}$ \\
\hline $\mathrm{N}$ & & 100 & 100 & 100 & 100 \\
\hline Normal & Mean & 8.6910 & 63.5678 & 64.8896 & 74.9428 \\
\hline Parameters ${ }^{\mathrm{a}, \mathrm{b}}$ & Std. Deviation & 6.37879 & 12.96069 & 23.94702 & 46.43570 \\
\hline Most Extreme & Absolute & .088 & .084 & .085 & .084 \\
\hline \multirow{2}{*}{ Differences } & Positive & .078 & .084 & .085 & .084 \\
\hline & Negative & -.088 & -.066 & -.069 & -.064 \\
\hline Test Statistic & & .088 & .084 & .085 & .084 \\
\hline Asymp. Sig. (2 & ailed) & $.057^{\mathrm{c}}$ & $.076^{\mathrm{c}}$ & $.070^{\mathrm{c}}$ & $.076^{\mathrm{c}}$ \\
\hline
\end{tabular}

Sumber : Data diolah output SPSS 22, 2019

Dari tabel 5 diketahui bahwa nilai signifikan tiap variabel lebih besar dari 0,05 . Hal ini juga dapat dilihat dari probability plot dari tiap variabel yang menunjukkan titik-titik menyebar disekitar garis diagonal dan mengikuti arah garis diagonalnya. Dari kedua hasil tersebut dapat disimpulkan bahwa data berdistribusi normal.
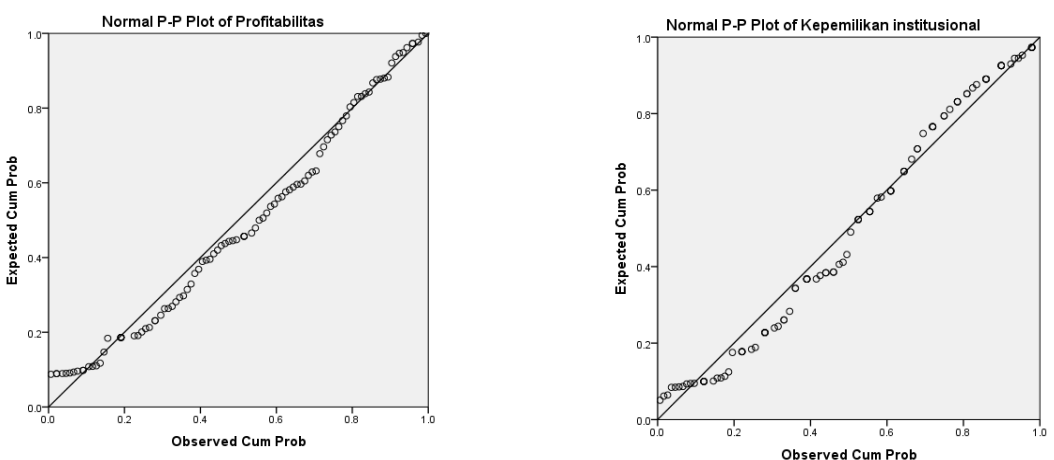

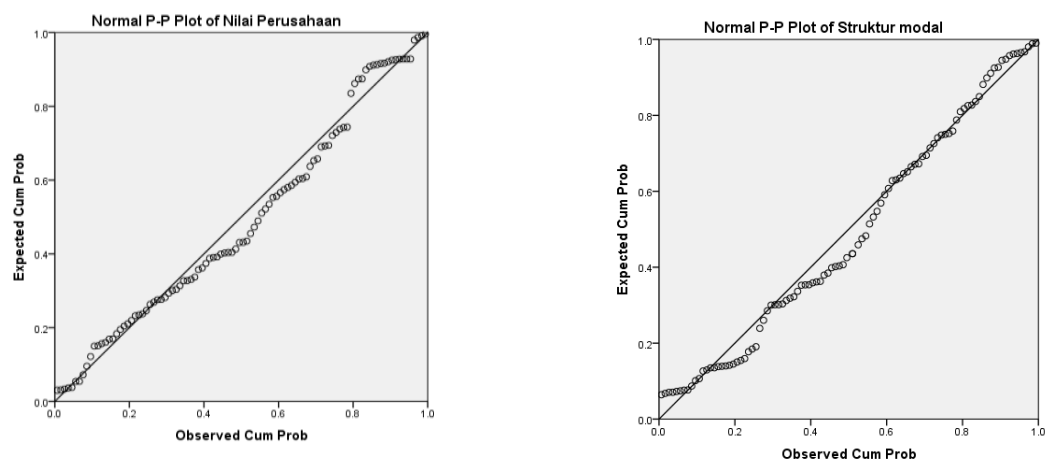

Gambar 3. Probability Plot

Tabel 6. Hasil Uji Multikolineritas

\begin{tabular}{clrr}
\multicolumn{3}{c}{ Coefficients $^{\mathbf{a}}$} & \\
\hline \multirow{2}{*}{ Model } & & \multicolumn{2}{c}{ Collinearity Statistics } \\
\cline { 3 - 4 } & & Tolerance & VIF \\
\hline \multirow{2}{*}{1} & Profitabilitas & .992 & 1.008 \\
\cline { 2 - 4 } & Kepemilikan Institusional & .992 & 1.008 \\
\hline
\end{tabular}

a. Dependent Variable: Nilai Perusahaan

Sumber : Data diolah output SPSS 22, 2019

Dari tabel 6 tersebut memperlihatkan semua variabel mempunyai nilai tolerance $>0,10$ yaitu $0,992>0,10$ dan nilai VIF $<10$ yaitu $1,008<10$. Sehingga disimpulkan bahwa model regresi pada penelitian ini tidak terjadi multikolineritas.

Uji autokorelasi dideteksi dengan menggunakan nilai Durbin Watson (DW). Hasil uji menunjukkan angka 0,825 sehingga data disimpulkan bahwa terjadi masalah autokorelasi. Maka akan diperbaiki menggunakan metode Cochrane-Orcutt.

Tabel 7. Hasil Uji Autokorelasi

Model Summary ${ }^{b}$

\begin{tabular}{lll}
\hline Model & Durbin-Watson & \\
\hline 1 & & $1.727^{\mathrm{a}}$ \\
\hline
\end{tabular}

Sumber : Data diolah output SPSS 22, 2019

Dari hasil tabel uji autokorelasi diatas dapat diketahui nilai Durbin Watson adalah 1,727 dengan $\mathrm{k}($ variabel independen $)=2$ dan $\mathrm{n}($ jumlah sampel $)=100$ sehingga diperoleh $\mathrm{dl} 1,6337$ dan du 1,7152 serta 4-du adalah 4-1,7152 =2,2848. Maka dapat diketahui bahwa nilai d terletak diantara du dan 4-du yaitu 1,7152 <1,727 <2,2848 Hal ini menunjukkan bahwa didalam model regresi tidak terjadi autokorelasi.

Uji hetersokedastisitas dapat dlihat di gambar 4 berikut:

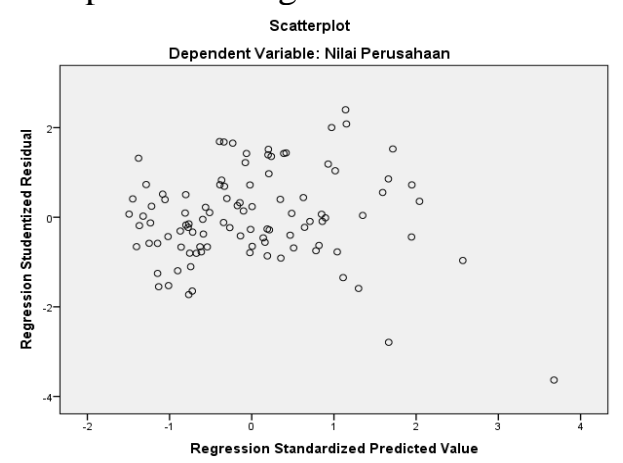

Sumber : Data diolah output SPSS 22, 2019

Gambar 4. Grafik Scatterplot

Dari hasil uji heteroskedastisitas dapat diambil kesimulan bahwa tidak terjadi heteroskedastisitas dikarenakan titik-titik tidak membentuk pola tertentu serta penyebaran titiktitik diatas dan dibawah angka nol pada sumbu Y.

c. Uji Regresi Linear Berganda

Hasil uji regresi linear berganda yaitu pengaruh profitabilitas dan kepemilikan institusional terhadap nilai perusahaan disajikan dalam tabel 8 berikut: 
Tabel 8. Hasil Regresi Linear Berganda

\begin{tabular}{|c|c|c|c|c|c|}
\hline \multirow[b]{3}{*}{ Model } & \multicolumn{3}{|c|}{ Coefficients $^{\mathrm{a}}$} & \multirow[b]{3}{*}{$\mathbf{t}$} & \multirow[b]{3}{*}{ Sig. } \\
\hline & $\begin{array}{r}\text { Unst } \\
\text { Co }\end{array}$ & $\begin{array}{l}\text { lardized } \\
\text { icients }\end{array}$ & $\begin{array}{c}\text { Standardized } \\
\text { Coefficients }\end{array}$ & & \\
\hline & B & Std. Error & Beta & & \\
\hline $\begin{array}{ll} & \text { (Constant) }\end{array}$ & 28.283 & 4.050 & & 6.983 & .000 \\
\hline Profitabilitas & .937 & .282 & .319 & 3.319 & .001 \\
\hline Kepemilikan Institusional & -.145 & .128 & -.110 & -1.140 & .257 \\
\hline
\end{tabular}

Tanda (+) menunjukkan terdapat hubungan positif yang searah antar variabel dependen dengan variabel independen, sedangkan tanda (-) menunjukkan hubungan negatif antar variabel independen dengan variabel dependen. Berdasarkan tabel 4.8 nilai konstanta pada persamaan regresi sebesar 28,283. Koefisien regresi variabel profitabilitas sebesar 0,937 yang artinya jika nilai $X_{1}$ (profitabilitas) meningkat sebesar $1 \%$ maka nilai perusahaan juga akan naik sebesar 0,937 dan koefisien untuk variabel kepemilikan institusional sebesar $-0,145$ yang artinya apabila nilai $X_{2}$ (kepemilikan institusional) meningkat sebanyak $1 \%$ sehingga nilai perusahaan akan menurun sebesar $-0,145$. Sehingga rumus persamaan regresi untuk menguji pengaruh variabel independen terhadap dependen adalah sebagai berikut:

$$
\begin{aligned}
& Y=\alpha+b 1 P+b 2 K I+e \\
& Y=28,283+0,937 P-0,145 K I+0,05
\end{aligned}
$$

\section{d. Uji Hipotesis}

Tabel 9. Hasil Uji Parsial (t)

\begin{tabular}{|c|c|c|c|c|c|}
\hline \multirow[b]{2}{*}{ Model } & \multicolumn{2}{|c|}{$\begin{array}{l}\text { Unstandardized } \\
\text { Coefficients }\end{array}$} & \multirow{2}{*}{$\begin{array}{c}\begin{array}{c}\text { Standardized } \\
\text { Coefficients }\end{array} \\
\text { Beta }\end{array}$} & \multirow[b]{2}{*}{$\mathbf{t}$} & \multirow[b]{2}{*}{ Sig. } \\
\hline & B & Std. Error & & & \\
\hline $\begin{array}{ll}1 & \text { (Constant) } \\
\end{array}$ & 28.283 & 4.050 & & 6.983 & .000 \\
\hline Profitabilitas & .937 & .282 & .319 & 3.319 & .001 \\
\hline Kepemilikan Institusional & -.145 & .128 & -.110 & -1.140 & .257 \\
\hline
\end{tabular}

Coefficients $^{\mathrm{a}}$

Sumber : Data diolah output SPSS 22, 2019

Tabel 9 di atas menunjukkan nilai signifikasi profitabilitas sebesar $0,001<0,05$ dan nilai t hitung profitabilitas adalah 3,319 sedangkan untuk t tabel sebesar 1,660 sehingga $t$ hitung $3,319>$ t tabel 1,660. Jadi bisa disimpulkan bahwa $H_{a}$ diterima profitabilitas berpengaruh terhadap nilai perusahaan. Sedangkan untuk nilai signifikasi kepemilikan institusional sebesar $0,257>0,05$ dan nilai $t$ hitung sebesar $-1,140$ serta $t$ tabel sebesar 1,660 ( $t$ hitung $-1,140<\mathrm{t}$ tabel 1,660). Sehingga disimpulkan bahwa $H_{o}$ diterima, kepemilikan institusional tidak memiliki pengaruh terhadap nilai perusahaan.

Tabel 10. Hasil Koefisien Determinasi

Model Summary ${ }^{b}$

\begin{tabular}{lcccc}
\hline Model & R & R Square & $\begin{array}{c}\text { Adjusted } \\
\text { R Square }\end{array}$ & $\begin{array}{c}\text { Std. Error of the } \\
\text { Estimate }\end{array}$ \\
\hline 1 & $.347^{\mathrm{a}}$ & .121 & .102 & 17.25348 \\
\hline
\end{tabular}

Sumber : Data diolah output SPSS 22, 2019

Tabel 10 memperlihatkan nilai R Square-nya sebesar 0,121 . Hal ini mengindikasikan bahwa $12,1 \%$ nilai perusahaan bisa diperjelas variasi variabel independen yaitu profitabilitas dan kepemilikan institusional (KI) sedangkan $87,9 \%$ dipengaruhi oleh faktor yang lainnya diluar penelitian seperti tingkat likuiditas perusahaan, ukuran perusahaan, dan corporate social responsibility dan lain-lain.

Uji interaksi Moderated Regression Analysis (MRA), digunakan untuk menguji hubungan antara variabel independen dengan variabel dependen dimana dalam hubungan terdapat faktor yang memperkuat atau sebaliknya memperlemah hubungan. 
Persamaan I:

Tabel 11. Regresi $X_{1}$

Coefficients $^{\mathrm{a}}$

\begin{tabular}{lrrrrrr}
\hline & \multicolumn{2}{c}{$\begin{array}{c}\text { Unstandardized } \\
\text { Coefficients }\end{array}$} & \multicolumn{2}{c}{$\begin{array}{c}\text { Standardized } \\
\text { Coefficients }\end{array}$} & & \\
\cline { 2 - 5 } Model & \multicolumn{1}{c}{ B } & Std. Error & Beta & T & \multicolumn{1}{c}{ Sig. } \\
\hline l(Constant) & 24.271 & 2.006 & & 12.098 & .000 \\
\hline Profitabilitas & .968 & .281 & & .330 & 3.439 & .001 \\
\hline
\end{tabular}

a. Dependent Variable: Nilai Perusahaan

Sumber : Data diolah output SPSS 22, 2019

$$
\begin{aligned}
& \mathbf{Y}=\boldsymbol{\alpha}+b_{1} X_{1}+\varepsilon \\
& \mathbf{Y}=\mathbf{2 4 , 2 7 1}+\mathbf{0 , 9 6 8} X_{1}+\varepsilon
\end{aligned}
$$

Hasil uji pada tabel regresi $X_{1}$ diperoleh nilai koefisien bertanda (+) yakni sebesar 0,968 yang artinya apabila nilai koefisien regresi $X_{1}$ (profitabilitas) meningkat sebesar $1 \%$ maka nilai perusahaan mengalami kenaikan sebesar 0,968. Nilai signifikasi profitabilitas sebesar 0,001 < 0,05. Sehingga diambil kesimpulan bahwa profitabilitas berpengaruh positif terhadap nilai perusahaan.

Tabel 12. Regresi $X_{2}$

\begin{tabular}{lccccc}
\hline & \multicolumn{3}{c}{ Coefficients $^{\mathbf{a}}$} \\
& $\begin{array}{c}\text { Unstandardized } \\
\text { Coefficients }\end{array}$ & $\begin{array}{c}\text { Standardized } \\
\text { Coefficients }\end{array}$ & & \\
\cline { 2 - 5 } Model & $\mathbf{B}$ & Std. Error & Beta & T & Sig. \\
\hline J(Constant) & 32.718 & 4.016 & & 8.147 & .000 \\
\hline Kepemilikan Institusional & -.186 & .133 & -.140 & -1.395 & .166 \\
\hline
\end{tabular}

a. Dependent Variable: Nilai Perusahaan

Sumber : Data diolah output SPSS 22, 2019

$$
\begin{aligned}
& \mathbf{Y}=\boldsymbol{\alpha}+b_{2} X_{2}+\boldsymbol{\varepsilon} \\
& \mathbf{Y}=\mathbf{3 2 , 7 1 8}-\mathbf{0 , 1 8 6} X_{2}+\boldsymbol{\varepsilon}
\end{aligned}
$$

Sesuai dengan tabel regresi $X_{2}$ diperoleh nilai koefisien bertanda (-) yakni sebesar -0,186 yang berarti apabila nilai koefisien regresi $X_{2}$ Kepemilikan Institusional (KI) mengalami kenaikan sebanyak $1 \%$ maka nilai perusahaan Y akan menurun sebesar 0,186. Akan tetapi hal ini tidak berlaku karena nilai signifikasi sebesar 0,166>0,05 interprestasinya kepemilikan

\begin{tabular}{|c|c|c|c|c|c|}
\hline \multirow[b]{2}{*}{ Model } & \multicolumn{2}{|c|}{$\begin{array}{l}\text { Unstandardized } \\
\text { Coefficients }\end{array}$} & \multirow{2}{*}{$\begin{array}{c}\begin{array}{c}\text { Standardized } \\
\text { Coefficients }\end{array} \\
\text { Beta } \\
\end{array}$} & \multirow[b]{2}{*}{$\mathbf{T}$} & \multirow[b]{2}{*}{ Sig. } \\
\hline & B & Std. Error & & & \\
\hline (Constant) & 18.594 & 2.377 & & 7.821 & .000 \\
\hline Profitabilitas & .882 & .264 & .300 & 3.341 & .001 \\
\hline Struktur Modal & .196 & .051 & .349 & 3.884 & .000 \\
\hline
\end{tabular}
institusional tidak berpengaruh terhadap nilai perusahaan. Sehingga apabila nilai kepemilikan institusional naik $1 \%$ maka nilai perusahaan akan tetap.

Persamaan II:

a. Dependent Variable: Nilai Perusahaan

Sumber : Data diolah output SPSS 22, 2019

$$
\begin{aligned}
& \mathbf{Y}=\boldsymbol{\alpha}+b_{1} X_{1}+b_{3} \mathbf{Z}+\boldsymbol{\varepsilon} \\
& \mathbf{Y}=\mathbf{1 8 , 5 9 4}+\mathbf{0 , 8 8 2} X_{1}+\mathbf{0 , 1 9 6 Z} \mathbf{Z}+\boldsymbol{\varepsilon}
\end{aligned}
$$

Tabel 13 di atas menunjukkan nilai koefisien profitabilitas sebesar 0,882 dengan signifikasi 0,001 dan nilai koefisien untuk variabel struktur modal sebesar 0,196 dengan nilai sig 0,000. Nilai koefisien dari kedua variabel tersebut bernilai positif dan memiliki nilai signifikasi $<0,05$ sehingga dapat disimpulkan bahwa apabila profitabitas dan struktur modal naik $1 \%$ maka nilai perusahaan juga akan naik sejumlah 0,882 dan 0,196 . 
Tabel 14. Regresi $X_{2}$ dan $Z$

Coefficients $^{\mathrm{a}}$

\begin{tabular}{lccccc}
\hline & \multicolumn{2}{c}{$\begin{array}{c}\text { Unstandardized } \\
\text { Coefficients }\end{array}$} & $\begin{array}{c}\text { Standardized } \\
\text { Coefficients }\end{array}$ & & \\
\cline { 2 - 5 } Model & $\mathbf{B}$ & Std. Error & Beta & t & Sig. \\
\hline (Constant) & 25.284 & 4.220 & & 5.992 & .000 \\
\hline Kepemilikan Institusional & -.142 & .125 & -.107 & -1.133 & .260 \\
\hline Struktur Modal & .205 & .053 & .365 & 3.862 & .000 \\
\hline
\end{tabular}

a. Dependent Variable: Nilai Perusahaan

Sumber : Data diolah output SPSS 22, 2019

$$
\begin{aligned}
& \mathrm{Y}=\alpha+b_{2} X_{2}+b_{3} \mathrm{Z}+\varepsilon \\
& \mathrm{Y}=25,284-0,142 X_{2}+0,205 \mathrm{Z}+\varepsilon
\end{aligned}
$$

Berdasarkan tabel regresi $X_{2}$ dan $\mathrm{Z}$ diperoleh nilai koefisien variabel Kepemilikan Institusional (KI) sebanyak -0,142 dengan nilai signifikasi 0,260 yang berarti kepemilikan institusional tidak memiliki pengaruh yang signifikan terhadap nilai perusahaan. Hal ini menunjukkan bahwa jika kepemilikan institusional meningkat sebesar $1 \%$ maka nilai perusahaan akan tetap. Sedangkan untuk nilai koefisien struktur modal sebesar 0,205 dengan signifikasi 0,000 . Nilai koefisien dari struktur modal bernilai positif dan signifikan sehingga apabila struktur modal naik 1\% maka akan menaikkan nilai perusahaan sebesar 0,205.

Persamaan III:

Tabel 15. Regresi $X_{1} * Z$ Coefficients $^{\mathrm{a}}$

\begin{tabular}{lrrrrr}
\hline & \multicolumn{2}{c}{$\begin{array}{c}\text { Unstandardized } \\
\text { Coefficients }\end{array}$} & $\begin{array}{c}\text { Standardized } \\
\text { Coefficients }\end{array}$ & & \\
\cline { 2 - 4 } Model & \multicolumn{1}{c}{ B } & Std. Error & Beta & \multicolumn{1}{c}{ T } & \multicolumn{1}{c}{ Sig. } \\
\hline r(Constant) & 19.662 & 2.133 & & 9.219 & .000 \\
\hline Profitabilitas & .176 & .274 & .060 & .642 & .523 \\
\hline Struktur Modal & .115 & .048 & .205 & 2.409 & .018 \\
\hline Moderasi X1 & .031 & .006 & .497 & 5.046 & .000 \\
\hline
\end{tabular}

a. Dependent Variable: Nilai Perusahaan

Sumber : Data diolah output SPSS 22, 2019

$$
\begin{aligned}
& \mathbf{Y}=\boldsymbol{\alpha}+b_{1} X_{1}+b_{3} \mathbf{Z}+b_{4} X_{1} * Z+\varepsilon \\
& \mathbf{Y}=\mathbf{1 9 , 6 6 2}+\mathbf{0 , 1 7 6} X_{1}+\mathbf{0 , 1 1 5} \mathrm{Z}+\mathbf{0 , 0 3 1} X_{1} * Z+\varepsilon
\end{aligned}
$$

Penarikan kesimpulan uji interaksi dapat diketahui dengan melihat pada persamaan II nilai signifikasi dari $b_{3}$ adalah sebesar 0,000 dan pada persamaan III nilai signifiksi $X_{1} * Z$ adalah sebesar 0,000 sehingga bisa diketahui bahwa nilai $\mathrm{Z}$ dan $X_{1} * \mathrm{Z}$ signifikan sehingga struktur modal merupakan variabel moderasi yang berjenis variabel pure moderator. Pure moderator dapat dilihat dari persamaan III yang menunjukkan nilai signifikasi $b_{1}$ sebesar 0,523 dan nilai signifiksi $b_{4}$ adalah sebesar 0,000 maka dapat diketahui $b_{2}$ tidak signifikan dan $b_{4}$ signifikan. Dari penjelasan tersebut dapat diambil kesimpulan bahwa struktur modal mampu memoderasi hubungan antara profitabilitas terhadap nilai perusahaan.

Tabel 16. Regresi $X_{2} * Z$

Coefficients $^{\mathrm{a}}$

\begin{tabular}{lccccc}
\hline Model & \multicolumn{2}{c}{$\begin{array}{c}\text { Unstandardized } \\
\text { Coefficients }\end{array}$} & $\begin{array}{c}\text { Standardized } \\
\text { Coefficients }\end{array}$ & T & Sig. \\
\hline & $\mathrm{B}$ & Std. Error & Beta & & \\
\hline J(Constant) & 23.312 & 5.108 & & 4.564 & .000 \\
\hline Kepemilikan Institusional & -.065 & .168 & -.049 & -.385 & .701 \\
\hline Struktur Modal & .275 & .114 & .489 & 2.404 & .018 \\
\hline Moderasi X2 & -.003 & .004 & -.147 & -.689 & .492 \\
\hline
\end{tabular}

a. Dependent Variable: Nilai Perusahaan

Sumber : Data diolah output SPSS 22, 2019

$$
\begin{aligned}
& \mathbf{Y}=\boldsymbol{\alpha}+b_{2} X_{2}+b_{3} \mathbf{Z}+b_{4} X_{2} * \mathbf{Z}+\boldsymbol{\varepsilon} \\
& \mathbf{Y}=\mathbf{2 3 , 3 1 2}-\mathbf{0 , 6 5} X_{2}+\mathbf{0 , 2 7 5} \mathbf{Z}-\mathbf{0 , 0 0 3} X_{2} * \mathbf{Z}+\boldsymbol{\varepsilon}
\end{aligned}
$$

Pada tabel $6 X_{2}$ dapat diketahui dengan melihat persamaan II nilai signifikasi dari $b_{3}$ adalah sebesar 0,000 dan pada persamaan III nilai signifiksi $X_{2} * \mathrm{Z}$ adalah sebesar 0,492 
sehingga dapat diketahui bahwa nilai $Z$ signifikan dan nilai dari $X_{2} * Z$ tidak signifikan sehingga struktur modal berpotensi menjadi variabel moderasi. Hal ini juga dapat dilihat dari persamaan III yang menunjukkan nilai signifikasi $b_{2}$ sebesar 0,701 dan nilai signifikasi $b_{4}$ sebesar 0,492 maka nilai $b_{2}$ dan $b_{4}$ tidak signifikan sehingga variabel ini berjenis homologiser moderator (variabel tersebut potensial menjadi variabel moderator). Dapat disimpulkan bahwa struktur modal belum mampu memoderasi hubungan antara kepemilikan institusional terhadap nilai perusahaan.

Agar dapat mengetahui apakah variabel moderasi bisa memperkuat atau memperlemah hubungan maka dapat dilihat dari nilai R Square. Nilai R Square bisa ditunjukkan pada tabel 17 untuk R Square $X_{1}$ dan $X_{1} * Z$ dan tabel 18 untuk $X_{2}$ dan $X_{2} * Z$

Tabel 17. R Square $X_{1}$ dan $X_{1} * Z$ Model Summary ${ }^{\mathrm{b}}$

\begin{tabular}{lrrrr}
\hline Model & R & R Square & Adjusted R Square & $\begin{array}{c}\text { Std. Error of the } \\
\text { Estimate }\end{array}$ \\
\hline 1 & $.330^{\mathrm{a}}$ & .109 & .099 & 17.28003 \\
\hline \multicolumn{5}{c}{ Model Summary } \\
\hline Model & $\mathrm{R}$ & $\mathrm{R}$ Square & Adjusted R Square & $\begin{array}{c}\text { Std. Error of the } \\
\text { Estimate }\end{array}$ \\
\hline 1 & $.627^{\mathrm{a}}$ & .393 & .373 & 14.41472 \\
\hline
\end{tabular}

Sumber : Data diolah output SPSS 22, 2019

Hasil R Square dapat diketahui bahwa nilai R Square pada regresi $X_{1}$ sebesar 0,109 dan pada regresi $X_{1} * Z$ nilainya sebesar 0,393 . Nilai R Square pada regresi $X_{1} * Z>$ dari pada regresi $X_{1}$ sehingga dapat disimpulkan bahwa struktur modal memperkuat hubungan antara profitabilitas terhadap nilai perusahaan.

Tabel 18. R Square $X_{2}$ dan $X_{2} * Z$

\begin{tabular}{|c|c|c|c|c|}
\hline \multicolumn{5}{|c|}{ Model Summaryb } \\
\hline Model & $\mathrm{R}$ & R Square & Adjusted R Square & Std. Error of the Estimate \\
\hline 1 & $.140^{\mathrm{a}}$ & .020 & .010 & 18.12210 \\
\hline \multicolumn{5}{|c|}{ Model Summaryb } \\
\hline Model & $\mathrm{R}$ & R Square & Adjusted R Square & Std. Error of the Estimate \\
\hline 1 & $.395^{\mathrm{a}}$ & .156 & .129 & 16.99369 \\
\hline
\end{tabular}

Sumber : Data diolah output SPSS 22, 2019

Uji R Square di atas menunjukkan nilai R Square pada regresi $X_{2}$ sebesar 0,020 dan pada regresi $X_{2} * Z$ nilainya sebesar 0,156 . Nilai $\mathrm{R}$ Square regresi $X_{2} * Z>$ dari pada regresi $X_{2} * Z$ sehingga diambil kesimpulan bahwa struktur modal memperkuat hubungan antara kepemilikan institusional terhadap nilai perusahaan.

\section{Pembahasan}

Berikut ini merupakan pembahasan dari hasil uji tiap hiotesis:

a. Pengaruh Profitabilitas Terhadap Nilai Perusahaan

Dalam hasil uji t tingkat signifikasi profitabilitas sebesar 0,001 $<0,05$ maka $H_{1}$ diterima. Sehingga profitabilitas berpengaruh terhadap firm value. Tingkat profitabilitas yang tinggi merupakan signal yang positif bagi para investor. Pada perusahaan Property dan Real Estate periode 2015-2018 tingkat profitabilitas mengalami decrease dari tahun ke tahun. Hal ini menyebabkan jumlah laba ditahan menurun sehingga nantinya dapat membuat perusahaan kekurangan dana, itu menggambarkan bahwa sinyal yang didapat oleh investor merupakan sinyal negatif sehingga berakibat pada menurunnya nilai perusahaan. Hasil penelitian ini selaras dengan penelitian Andreas Aryanto Nong Moa (2017) yang menyatakan bahwa profitabilitas berpengaruh terhadap nilai perusahaan. Semakin naik atau tinggi nilai ROE maka semakin efisien juga manajemen perusahaan dalam menggunakan modal internal (modal sendiri). Tingkat ROE pada perusahaan property dan real estate periode 2015-2018 mengalami penurunan tiap tahun dan diikuti oleh menurunnya nilai perusahaan. 


\section{b. Pengaruh Kepemilikan Institusional Terhadap Nilai Perusahaan}

Hasil uji pada penelitian menunjukkan tingkat signifikansi sebesar 0,257>0,05 sehingga $\mathrm{H}_{2}$ ditolak. Nilai koefisien kepemilikan institusional adalah sebesar $-0,145$ yang berarti berpengaruh negatif. Dapat diambil kesimpulan bahwa kepemilikan institusional tidak berpengaruh terhadap nilai perusahaan. Kepemilikan Institusional (KI) dengan tingkat ratarata 63,57\% merupakan pemilik mayoritas. Menurut Pound (1998) "investor institusional mayoritas memiliki kecenderungan untuk berkompromi atau berpihak dengan manajemen dan mengabaikan kepentingan pemegang saham minoritas. Anggapan bahwa pihak manajemen sering mengambil tindakan atau kebijakan yang tidak optimal dan cenderung mengarah kepada kepentingan pribadi mengakibatkan stategi aliansi antara pihak investor institusional dengan pihak manajemen ditanggapi negatif oleh pasar". Hal ini menunjukkan kepemilikan institusional ini tidak dapat mengoptimalkan fungsi pengawasan yang dimilikinya sehingga kepemilikan institusional ini tidak memberikan pengaruh terhadap nilai perusahaan. Hasil dalam penelitian ini sejalan dengan penelitian M. Rizky Alamsyah (2016) dan Muhammad Arif Anugrah (2018), akan tetapi penelitian ini bertentangan dengan dengan penelitian Putri Aulia Rahmadina (2017) yang membuktikan bahwa kepemilikan institusional berpengaruh terhadap nilai perusahaan.

\section{c. Pengaruh Profitabilitas Terhadap Nilai Perusahaan dengan Struktur Modal Sebagai Variabel Moderasi}

Berdasarkan hasil penelitian dapat diketahui bahwa struktur modal sebagai variabel moderasi yang berjenis pure moderator sehingga $\mathrm{H}_{3}$ dapat diterima. Dapat dilihat dari tabel 15 nilai R Square pada regresi $X_{1} * Z$ yakni $0,393<0,109$ maka struktur modal memperkuat hubungan profitabilitas terhadap nilai perusahaan. Sehingga dapat disimpulkan bahwa struktur modal mampu memoderasi hubungan antara profitabilitas terhadap nilai perusahaan. Dalam penelitian ini dapat diketahui bahwa nilai struktur modal dari periode ke periode selanjutnya juga mengalami penurunan. Penurunan ini tidak terjadi selama satu tahun tetapi tiap tahun mengalami penurunan dari tahun 2015-2018 sehingga memungkinkan perusahaan untuk tidak hanya berhutang melainkan harus mendapatkan dana dari pihak lain yakni dari investor dengan cara menerbitkan saham baru. "Semakin tinggi penggunaan utang pada struktur modal maka kan semakin tinggi tingkat pengembalian atas ekuitas dalam profitabilitas perusahaan. Profitabilitas yang meningkat dapat meningkatkan nilai perusahaan. Sebaliknya peningkatan utang dapat diartikan oleh pihak luar tentang kemampuan perusahaan untuk membayar kewajiban di masa yang akan datang atau adanya risiko bisnis yang rendah, sehingga akan direspon secara positif oleh pasar (investor)" (Wardhani, 2017).

\section{d. Pengaruh Kepemilikan Institusional Terhadap Nilai Perusahaan dengan Struktur Modal Sebagai Variabel Moderasi}

Berdasarkan hasil penelitian menunjukkan nilai $\mathrm{R}$ Square regresi $X_{1}>X_{2}$ nilainya yakni 0,156>0,020 sehingga struktur modal memperkuat hubungan antara kepemilikan institusional terhadap nilai perusahaan, akan tetapi hal ini tidak berlaku karena pada tabel 16 menunjukkan bahwa struktur modal belum mampu menjadi variabel moderasi. Selain itu hasil uji t juga membuktikan bahwa kepemilikan institusional tidak berpengaruh terhadap nilai perusahaan. Sehingga $\mathrm{H}_{4}$ ditolak, struktur modal tidak mampu memoderasi hubungan antara kepemilikan institusional terhadap nilai perusahaan. Pada penelitian ini diketahui bahwa nilai struktur modal dari tahun ke tahun juga mengalami penurunan. Penurunan ini terjadi bukan karena penurunan jumlah utang. Tetapi lebih tepatnya karena tingkat utang yang mengalami kenaikan. Kenaikan tingkat utang dapat disebabkan karena pengendalian penggunaan utang dan pengawasan yang kurang efektif oleh pihak institusional terhadap kinerja manajemen. Pada penelitian ini kepemilikan institusional menunjukkan nilai rata-rata 63,57\% merupakan pemilik mayoritas. Menurut Pound (1998) bahwa "investor institusional mayoritas memiliki kecenderungan untuk berkompromi atau berpihak dengan manajemen yang sering mengambil tindakan atau kebijakan yang tidak optimal dan cenderung mengarah kepada kepentingan pribadi mengakibatkan stategi aliansi antara pihak investor institusional dengan pihak manajemen ditanggapi negatif oleh pasar". "Utang yang besar di perusahaan dapat meningkatkan resiko kemungkinan tidak mampu membayar kewajiban. Tetapi dengan 
kondisi tersebut dapat memperlemah hubungan antara institusional dengan nilai perusahaan, yang bisa disebabkan investor lebih memilih perusahaan dengan tingkat risiko kebangkrutan yang rendah" (Wardhani, 2017).

\section{E. SIMPULAN DAN SARAN}

Berdasarkan hasil analisis data dalam penelitian maka diinterpretasiakan dan disusun kesimpulan sebagai berikut: (1) Variabel profitabilitas yang di proksikan menggunakan ROE (Return On Equity) berpengaruh terhadap firm value. (2) Variabel kepemilikan institusional tidak berpengaruh terhadap nilai perusahan. (3) Variabel Capital Structure mampu memoderasi dan memperkuat hubungan antara profitabilitas terhadap nilai perusahaan. (4) Variabel struktur modal tidak mampu memoderasi hubungan antara kepemilikan institusional terhadap nilai perusahaan pada Perusahaan Property dan Real Estate di Bursa Efek Indonesia Periode 2015-2018.

Berikut ini merupakan saran peneliti kepada beberapa pihak diantaranya yaitu: (1) Manfaat untuk investor, sebaiknya harus mengumpulkan highlight informasi mengenai profitabilitas perusahaan, karena profitabilitas berdampak pada tinggi-rendahnya nilai suatu perusahaan. (2) Bagi perusahaan Property dan Real Estate penentuan kebijakan yang akan berdampak pada tingkat keuntungan harus lebih diperhatikan mengingat pada tahun belakangan ini minat pembeli menurun dan melakukan pengawasan yang lebih efektif lagi terhadap perusahaan. (3) Bagi penelitian selanjutnya dapat menggunakan proksi lebih dari satu dalam variabel. Serta meningkarkan jumlah sampel penelitian serta melibatkan sektor industri yang lain agar lebih bisa mencerminkan reaksi dari pasar modal secara keseluruhan.

\section{REFERENCE}

Alamsyah, M. Rizky. (2016). "Pengaruh kepemilikan manajerial, kepemilikan institusional, kebijakan deviden, dan kebijakan hutang terhadap nilai perusahaan”. (Doctoral dissertation, Sekolah Tinggi Ilmu Ekonomi Perbanas).

Anugrah, Arif Muhammad. (2018). "Pengaruh kebijakan hutang, ukuran perusahaan, kebijakan deviden, dan kepemilikan institusionalterhadap nilai perusahaan property dan real estate periode 2012-2016”. (Doctoral dissertation, Sekolah Tinggi Ilmu Ekonomi Perbanas).

Brigham, E. F. Dan John F. Houston. 2011. "Dasar-Dasar Manajemen keuangan buku, 2”.

Hanafi, M.M. (2013). "Manajemen Keuangan”. Yogyakarta: BPFE.

Hermuningsih, S. (2012). "Pengaruh profitabilitas, size terhadap nilai perusahaan dengan sruktur modal sebagai variabel intervening". Jurnal siasat bisnis, 16(2).

Jensen, M. C., \& Meckling, W. H. (1976). "Theory of the firm: Managerial behavior, agency costs and ownership structure". Journal of financial economics, 3(4), 305-360.

Keown, A. J., \& Scott Jr, D. F. John D. Martin, J. William Petty 2010. "Dasar-dasar Manajemen Keuangan", 2.

Moa, Andreas Aryanto Nong. (2017). "Pengaruh profitaabilitas, kebijakan hutang, kebijakan deviden, dan struktur modal terhadap nilai perusahaan property dan real estate di BEI tahun 2012-2014”. (Doctoral dissertation, Sekolah Tinggi Ilmu Ekonomi Perbanas).

Pasaribu, M. Y., \& Sulasmiyati, S. (2016). "Pengaruh Struktur Modal, Struktur Kepemilikan Dan Profitabilitas Terhadap Nilai Perusahaan Pada Perusahaan Sektor Industri Dasar Dan Kimia Yang Terdaftar Di BEI Tahun 2011-2014”. Jurnal administrasi bisnis, 35(1), 154164.

Pound, J. 1998. "Proxy Contests and the Efficiency of Shareholder Oversight". Jouenal of Financial Economics, 20, pp.237-65.

Rahmadina, P.A. (2017). "Pengaruh Kepemilikan Institusional, Kebijakan Hutang, Ukuran Perusahaan Dan Kinerja Prusahaan Terhadap Nilai Perusahaan”. Skripsi Progam Sarjana Ekonomi Dan Bisnis. Program Sarjana Ekonomi. Jakarta : Universitas Islam Negeri Syarif Hidayatullah. 
Resdianty, Wahyu. (2018). "Pengaruh kepemlikikan manajerial, kepemilikan institusional, profitabilitas, dan likuiditas, terhadap nilai perusahaan dengan struktur modal sebagai variabel intervening". (Doctoral dissertation, Sekolah Tinggi Ilmu Ekonomi Perbanas).

Simanjuntak, T. B. P., \& Pangestuti, I. R. D. (2019). "Efek Kepemilikan Institusional, Profitabilitas, Ukuran Perusahaan Dan Pertumbuhan Penjualan Terhadap Nilai Perusahaan Dengan Struktur Modal Sebagai Variabel Intervening”. (Doctoral dissertation, Fakultas Ekonomika \& Bisnis).

Sugiarto. 2009. "Struktur modal, Struktur kepemilikan perusahaan, Permasalahan keagenan dan Informasi asimetris". Yogyakarta. Graha Ilmu.

Sujarweni, V. W. (2015). “Analisis Laporan Keuangan”. Yogyakarta: Pustaka Baru Press.

Sujarweni, V. W. (2012). "Statistik Untuk Penelitian”. Yogyakarta: Graha Ilmu.

Wahab, A., \& Mulya, A. A. (2017). "Analisis Pengaruh Pengungkapan Corporate Social Responsibility (Csr), Kepemilikan Institusional, Dan Ukuran Perusahaan Terhadap Nilai Perusahaan (Studi Empiris Pada Perusahaan Property dan Real Estate Yang Terdaftar Di Bursa Efek Indonesia Periode 2009”. Jurnal Akuntansi dan Keuangan, 1(2).

Wardhani, T. S., Chandrarin, G., \& Rahman, A. F. (2017). "Pengaruh Kepemilikan Institusional terhadap Nilai Perusahaan dengan Keputusan Investasi, Keputusan Pendanaan dan Kebijakan Dividen sebagai Variabel Moderasi”. Jurnal Ilmiah Ilmu Akuntansi, Keuangan dan Pajak, 1(2).

www.idx.co.id.

www.mpi-update.com 